\title{
The Influence of Work Culture, Work Stress to the Job Satisfaction and Employees Performance in the State Treasury Service Office in Jakarta, Indonesia
}

\author{
Khuzaeni' ${ }^{1}$, MS. Idrus, Djumahir, Solimun ${ }^{2}$ \\ 1.2. Doctoral Program of Management Sciences Faculty of Economics and Business University of Brawijaya \\ Malang.
}

\begin{abstract}
This research was carried out starting from the phenomenon of the performance which was not maximized by the employees of State Treasury Service Office in Jakarta. Based on the literature there was a suspicion that the performance which was not maximized due to a weak work culture, work stress and the decreasing of job satisfaction. The purpose of this research was to quantify and explain the relationship between variables of work culture, work stress, job satisfaction and employees performance in the State Treasury Service Office Jakarta. The research method was using quantitative methods. Research locations were located in six State Treasury Service Offices in Jakarta with samples of 152 employees. Data analysis technique was using Partial Least Square (PLS) with the help of Smart program. The results showed that the work culture has no effect on job satisfaction. Work stress has no effect on job satisfaction. Work culture affected to the employee performance. Work stress had no effect on employee performance. Job satisfaction had no effect on performance. The implication of this research was to establish a strong working culture to decrease work stress and increase job satisfaction which ultimately improved employee performance.
\end{abstract}

Keywords: Work Culture, Work Stress, Job Satisfaction and employee performance

\section{Introduction}

In the world of employment, work stress problems often experienced by employees and had an influence on the employee performance, while the employee's performance was affected by many things including work culture and job satisfaction [1]. High job satisfaction would improve performance. If low levels of satisfaction it would lower the performance [2]. Ruyter [3] explained that when stress was in high levels, job satisfaction decreased and when the stress level was low then the performance would be improved.

Haque [4] stated that job satisfaction was influenced by the function and status of employees within an organization where high rank employees would feel more satisfied because they had greater autonomy, more varied jobs and had the freedom to do the assessment. Dwaikat [5] and Imtiaz [6] stated that job satisfaction affected the performance when they got the best out of the organization. Robbins [7] explained that the factors leading to the emergence of stress at work were: task demands, role demands, interpersonal demands, organizational leadership and organizational structure. Gbolahan [8] stated the stress was caused by uncertainty, discrepancy between expectations and reality within the organization.

One of the offices which had not yet owned up the maximum performance was the State Treasury Service Office in Jakarta. The office was the public service office under the Directorate General of State Treasury, Finance Ministry of Republic of Indonesia. State Treasury Service Office played an important role in supporting the smooth development. In general, bureaucratic reforms had improved the quality of service and laying good government foundations, but still had some weaknesses in aspects of governance, institutional and human resource management that was likely not performing optimally.

Performance which was not in the maximum level was suspected that the work culture, job stress and job satisfaction were decreasing. Based on previous studies the relationship between the variables of work culture, work stress, job satisfaction and employee performance research resulted vary. Some claimed work culture could reduce stress and effect on employee performance [9]. There was also a work culture could not improve the performance of employees [10]. Stress did not affect job performance and job satisfaction among employees, [11], [12], [13].

Based on this phenomenon and the variation of the previous research results, it was used as a background for further research. The purpose of this research was to measure and explain the influence of work culture on work satisfaction; work stress on job satisfaction; work culture on employee performance; work stress on employee performance, and job satisfaction on employee performance. 


\section{Review Of Related Literature}

\subsection{The Concept of Work Culture}

Robbin [14] explained that the work culture was practically contained some definitions of the pattern of values, attitudes, behaviour, intention and results of the work, including any instrument, work systems, technology and the language it used. Culture was closely linked to the values and the environment that lead to the meaning and philosophy of life, which would influence the attitudes and behaviour at work. Culture was the result of life experiences, habits, and the selection process (accept or reject) the norms that exist in a social interaction or put himself in the middle of a particular work environment.

Hofstede [15] categorized cultural layers to classify people according to the habits of their environment: 1. National level, based on a country.

2. Local level (regional), and / or ethnic, and or religion, and or language.

3. Difference sex level (gender).

4. Generation level, such as parents with young children.

5. Social levels, associated with education, and occupation or profession.

6. Levels of the organization or company.

Individual performance of an organization community was influenced by various factors, one of which was a good and conducive organizational climate to make how a person felt comfortable and safe carrying out the work according to his profession. Someone who felt safe and comfortable in doing his job, a profession was related to the job or profession was said to be a work culture that was reflected in the work day behaviour. Of course, the behaviour was expected to be consistent with the vision and mission of the organization, it could be said that the behaviour of a person working behaviour was directly or indirectly influenced by the value of organizational culture manifested into work culture. That close relationship as being suggested by Kotter and Haskett [16] put the work culture in the company's first order, namely: (1) work culture, (2) the structure, systems, formal policy plan, (3) leadership, (4) organized environmental and competitive.

\subsection{The Concept of Work Stress}

Bunk et al [17] said that job stress was a result of a mismatch between what the individual wanted and what was provided by the job, or the inappropriateness between job demands and the employees' capabilities. Ross and Altmeir [18] said that job stress was the interaction between working conditions and employees characteristics, where the demands of the job exceed the capabilities to deal with it. According to Luthans [19], the sources of job stress included the sources of stress outside the organization, made up of social and technological change, economic conditions, moving house, racial and community circumstances. Individual sources of stress, such as role conflict, ambiguity, change, life and career.

Behr and Newman [20] found that there were three types of personal symptoms that appeared in the workers due to work stress. Those symptoms were psychological symptoms, such as emotional and cognitive issues that rose under conditions of work stress. The stress which were included in psychological symptoms were anxiety, tension, confusion, frustration and anger, boredom, job dissatisfaction, mental fatigue, decreased intellectual function, and lack of concentration and declining confidence. Physical symptoms were physical health decline gradually, which was included in physical symptoms such as increased heart rate, blood pressure, physical exhaustion, symptoms of behaviour was behaviour that arise as a result of work stress were included in the behavioural symptoms such as delay and avoid the work, performance and low productivity.

\subsection{The Concept of Work Satisfaction}

Job satisfaction was the emotional attitude of fun and loving his job. This attitude was reflected by the morale, discipline and work performance. Job satisfaction was enjoyed in the work [21]. Job satisfaction was: "An expression of happy feeling and positive which was the result of job assessment or work experience [22]. Job satisfaction was employee satisfaction towards his job. That feeling was a reflection of the adjustment between what was expected of employees from work [23].

Robbins [24] said that job satisfaction was as an individual general attitude towards his job. Job satisfaction was a reflection of the characteristics of a better job to make higher job satisfaction.

\subsection{Employees Performance}

Bernardin and Russel [25], proposed six primary criteria that could be used to measure performance, the quality which was the degree to which the process or the results of the implementation of approaching perfection or close to the expected goals; Quantity was the quantity produced. Timeliness is the degree to which an activity was completed at the desired time with respect to coordinating other outputs and the time available for other activities. Cost effectiveness was the degree to which the implementation of the human resources, finance, technology, and materials were maximized to achieve the highest yield or reduction of loss of each unit 
of resource use. The need for control was the degree to which an employee could perform the functions of a job, regardless of the supervision of a supervisor to prevent actions that were less desirable and interpersonal impact was the degree to which employees maintained self-esteem, goodwill and cooperation among colleagues and subordinates. Furthermore Malthis and Jacson [26] identified five major standards in performance assessment, such as: quantity of output; quality output; Long term; presence in the workplace and cooperative attitude.

\subsection{Research Design}

\section{Research Method}

The research was designed by using a quantitative approach. The type of research used in this research was explanatory. The research locations were in State Treasury Services office in Jakarta. Primary and secondary data were collected by cross section that was research a particular time by using the number of respondents. Data were collected directly to the location of the research.

\subsection{Population and Research Sample}

In this research, the first step in the selection of respondents was to determine the population, after the population had been known; the withdrawal of a representative sample of the population was set. The populations in this research were all employees scattered on the State Treasury Service Office with the 280 employees' numbers entirely. Sampling technique used in this research was stratified proportional random sampling, in which samples were taken for each stratum in proportion (ratio) and strata corresponding to the total population. [27] The determination of the samples number used in this research was using Slovin formula with the sample totaled of 152 .

\subsection{Data Analysis Method}

The analysis used in this research was a quantitative analysis. The analysis was used to describe the findings based on the use of instruments such as questionnaires which was scored in the form of quantitative figures. This research was used PLS (Partial Least Square) approach.

The reason for this research by using PLS (Partial Least Square) approach was that PLS was a powerful method of analysis since it could be applied at all scales of the data, did not require a lot of assumptions and sample size should not be large [28]. When the quantitative analysis result was not optimal, the qualitative analysis would support it to obtain qualitative information. That information was obtained through interviews with several informants and they were part of the respondents.

\subsection{Description of State Treasury Service Office (KPPN) Jakarta \\ IV. RESULT AND RESEARCH DISCUSSION}

State Treasury Service Office was the technical areas of the Directorate General of State Treasury support which supported the treasury functions. Directorate General of State Treasury was as an element of executing most of the main tasks of Ministry of Finance to do the formulation and implementation of policies and technical standardization in the field of budget revenues and expenditures.

To finish these tasks, the Directorate General of State Treasury's vision was to become a professional treasury management, transparent and accountable in the process of realizing an independent and prosperous nation. In order to achieve this vision, the mission should be completed by the Directorate General of State Treasury was managing the budget carefully, responsibly and transparently, empowering the state budget according to the financial condition of the country to support government policies in order to control and economic development and improving the welfare of the nation. Another thing to do was to perform the task as framers, implementation and technical standardization in the field of the state treasury.

\subsection{Respondents Identity}

The respondent identities in this research were civil service office of State Treasury Service Office (KPPN), a description of the identity of the respondents as follows Table 1.:

Table 1. Respondents Identity

\begin{tabular}{|l|l|l|l|}
\hline No & Description & Amount & $(\%)$ \\
\hline \multicolumn{2}{|l|}{ Sex of Respondents } & 106 & 72,45 \\
\hline 1 & Male & 46 & 27,55 \\
\hline 2 & Female & 152 & 100 \\
\hline Amount & 20 & 18,56 \\
\hline Age of Respondents & 45 & 27,54 \\
\hline 1 & $0-30$ years & \multicolumn{2}{|l|}{51 Page } \\
\hline 2 & $30-40$ years & &
\end{tabular}




\begin{tabular}{|l|l|l|l|}
\hline 3 & $40-50$ years & 77 & 47,31 \\
\hline 4 & $>50$ years & 10 & 6,59 \\
\hline Amount & 152 & 100 \\
\hline Education & SMA (Senior High School) & 21 & 18,56 \\
\hline 1 & D1/D3 (Diploma) & 45 & 27,54 \\
\hline 2 & SI (Bachelor Degree) & 76 & 47,31 \\
\hline 3 & S2 (Master Degree) & 10 & 6,59 \\
\hline 4 & 152 & 100 \\
\hline Amount & \multicolumn{3}{|l|}{} \\
\hline Employee Tenure & 30 & 18,56 \\
\hline 1 & $0-10$ years & 76 & 47,54 \\
\hline 2 & $10-15$ years & 46 & 27,31 \\
\hline 3 & $15-20$ years & 10 & 6,59 \\
\hline 4 & $>20$ years & 152 & 100 \\
\hline Amount &
\end{tabular}

Male respondents of 72.45 percent were more than women which only 27.55 percent. The data indicated that the nature of work at the Jakarta State Treasury Service Office needed more male employees than female employees. Jakarta KPPN age composition was quite ideal. The employees aged over 50 years were having the amount of at least $6.59 \%$, to the age of 50 years were directed to carry out the planning work. Besides the overall composition of the State Treasury Service Office in Jakarta were in the productive age, where more aged 0 - 30 years $18.56 \%, 30$ to 40 as much as $27.54 \%$. Young age's employees could support the ministry and treasury Jakarta that required speed, not knowing the time and the level of risk that could be run very well. Employees education level were educated in senior high school level which were around $18.56 \%$, this condition indicated that there was still the Employees limitations in developing information technology and strategic thinking power in the management of state finances. Service activities were pretty solid and the higher the capacity of its existence required employees who have a higher education in order to develop the ability to do services to all partners.

Nevertheless, D1/D3 education were as much as 27.54 percent, $47.31 \mathrm{~S} 1$ and S2 as much as 6.59 percent. The great composition for D3 levels to master could cover the shortfall Employees who had high school education level that did not reduce the performance of the service to all existing stakeholders. D3 level who were graduated from STAN were field technical human resources. With higher education was the internal force of the State Treasury Service Office Jakarta was highly profitable and was expected to support a quality service.

Most respondents had a working time of between 10 years to 15 years around $47.54 \%$. Employees composition who have 10 years more experience than the less than 10 years were showed that the State Treasury Service Office in Jakarta had employees that were ready to be assigned to serve partners. A high experience indicated that employees had the appropriate skills and experience and had not many obstacles in performing their duties.

\subsection{Hypothesis Testing result}

The results of hypothesis testing with Partial Least Square (PLS) analysis showed that 4 hypothesis was stated had no significant effect, whereas a significant hypothesis stated that work culture influenced on employee performance because of the estimation results indicated that T-Statistic> 2. Hypothesis testing was done by partially between the independent variables with the dependent variable. The results of hypothesis testing were presented in Table 2. :

Tabel 2. Hypothesis Testing result

\begin{tabular}{|ll|l|l|l|}
\hline \multicolumn{2}{|l|}{ Correlation Between Variables } & $\begin{array}{l}\text { path } \\
\text { coefficient }\end{array}$ & T-Statistic & Information \\
\hline Work Culture X1 $\quad$ > Work Satisfaction Y1 & 0.373 & 1.881 & insignificant \\
\hline Work Stree X2 $\quad$ > Work Satisfaction Y1 & 0.239 & 1.256 & insignificant \\
\hline Work Culture X1 -> Employess Performance Y2 & 0.436 & 2.297 & Significant \\
\hline Work Stress X2 -> Employess Performance Y2 & 0.268 & 1.400 & insignificant \\
\hline Work Satisfaction Y1 -> Employess Performance Y2 & 0.341 & 1.378 & insignificant \\
\hline
\end{tabular}




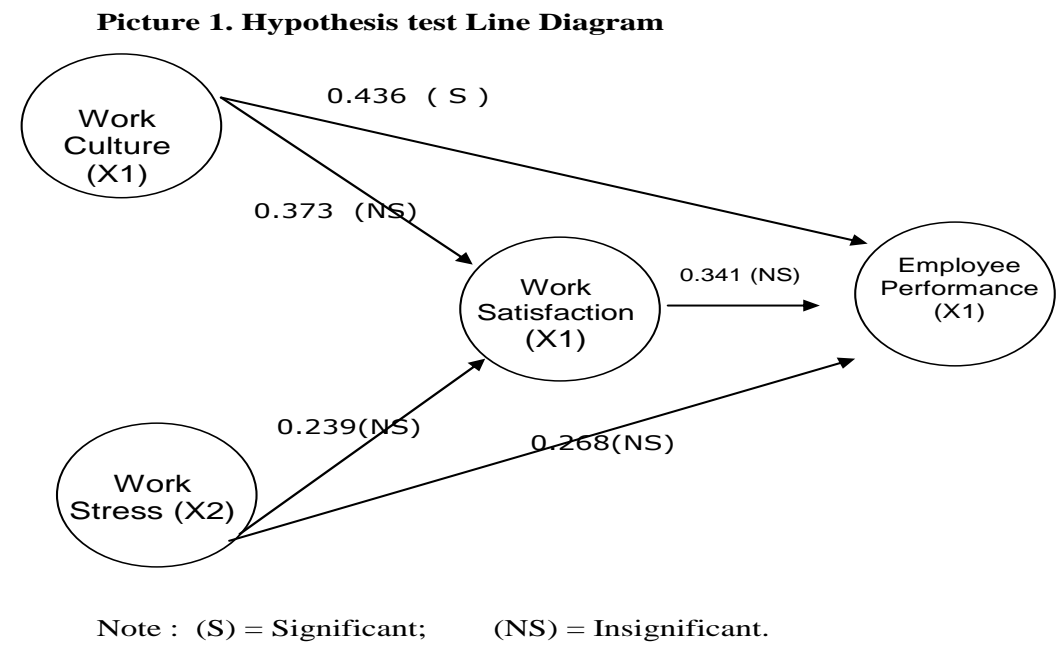

\subsection{Discussion}

The results of the analysis stated that the work culture on job satisfaction was not significantly affected. Employees of State Treasury Service Office Jakarta had confidence that the current work culture emphasized employees should increase labour productivity in the industry that excellent service to the community in its implementation had not been achieved yet could increase employee job satisfaction. These results differ from the results of research conducted by Kumar (2010) which stated there was the influence of work culture on job satisfaction. Strong work culture helped the employees understood the duties and functions of financial services. (Robbins and Judge, 2007). Each job had a distinction one another. Differences could be identified by the way they solved problems, how they acted and values espoused, the treatment led to the behaviour of subordinates and subordinates and superiors. The work culture of Jakarta State Treasury Service Office showed that they still need to have improvement in order to create a strong work culture that could reduce job stress and job satisfaction which ultimately improved employee performance. However, the analysis stated that culture significantly influenced the employee performance. Work culture that emphasized high productivity that employees work despite declining job satisfaction evidently increased performance because employees felt that the work that had been done bound regulatory organization that must be implemented.

The results of this research support the research conducted by Jaharuddin (2009); Mohd Nor Liyana (2010); Samartha (2009) showed a direct relationship to the performance work culture.

Work Stress analysis results on job satisfaction showed no significant influence value. Obtaining these results implied that excess workload, task demands, time constraints demand role had established job stress. Experienced job stress resulted in decreased job satisfaction. The results of this research supported the results of research conducted by Kasmi (2010) which suggested a negative effect of work stress on job satisfaction.

The results of the analysis stated that job stress had no significant effect on employee performance. These results indicated that although they had stress but the symptoms were still within tolerance or not so severe as they tried to find a solution how to complete the work in accordance with the target organization. This research supported previous research by Ahsan (2009); Womble (2010) which stated work stress had no effect on the performance of the employees

The results of the analysis, the effect of job satisfaction on employee performance demonstrated the value effect which was not significant. Obtaining this result implied that job satisfaction was important in improving employee performance, although the performance of the employees had been successful, but it was not because of job satisfaction, but through the work culture of high pressure to employee productivity.

These results were contrasted with a research conducted by Ahsan (2009) which stated positively related to job satisfaction and significant impact on employee performance. Positive relationship to job satisfaction Employee Performance meant that both job satisfactions would have an impact on improving employee performance.

\subsection{Conclusion}

\section{Conclusion And Suggestion}

Work Culture had not been able to improve on employee work satisfaction of State Treasury Service Office in Jakarta. This was because it had been the enactment of the culture that suppressed its employees for high productivity in the society service. Given these pressures lead to decreased employee satisfaction. The work dissatisfaction that accumulated each day resulted in job stress. However, employee stress of State 
Treasury Service Office still within tolerable limits so that they could still perform well performance. Good performance was not due to job satisfaction, but of the culture that pushed employees to have high labour productivity by applying the rules and periodic competency tests.

\subsection{Suggestion}

1. Working quickly was an indicator which had not built a work culture yet. Therefore, the work speed in service to the community was becoming important and needed to be improved.

2. The useful work and beneficial for organizations that had not yet developed an indicator of job satisfaction. Job satisfaction was the deciding factor in implementing a good performance so tha it was necessary to get the attention of the manager in caring employees' conditions.

3. In time work completion had not been able to build a good performance, then the timeliness in completing the task should receive the serious attention of the manager.

\section{Reference}

[1] Kazmi, Rubina, Shehla Amjad, dan Delawar Khan. 2008. Occupational Stress and its Effect on Job Performance A Case Study of Medical House Officers of District. J ayub Med Coll Abbottabad

[2] Timmreck, Thomas, 2001, California State University, San Bernardino, California, "Managing Motivation and Developping Job Satisfaction in The Healt Care Work Enviroment”. The Health care Manajer : Sep 2001;20,1; ABI/INFORM Research, pg 42.

[3] Ruyter J.C. de, Jong, A. de, en M.G.M Wetzels, (2009), Antecedents and consequences of environmental stewardship 5 in boundary-spanning B2B teams, Journal of the Academy of Marketing Science, 37 (4), 470-487.

[4] Haque (2009) Assessment of the human stress response : neurological, biochemical, and psychological foundations Journal of International Business Studies,Fall, pp. 76-88.

[5] Dwaikat (2008), Work Stress And Employee Performance In Banking Sector Evidence From District Faisalabad, Pakistan

[6] Imtiaz,2009 Imtiaz (2009) Impact workstress to performance and Satisfaction. Journal The Social Science, 38 : $233-250$.

[7] Robbin, S.P. 2003. Perilaku Organisasi. Jilid 2. PT Indeks. Jakarta.Robin, D.P. and E.R.

[8] Gbolahan dan Al-Qahtany,D mohammed.2005. The Iinfluence Of Performance Appraisal On Organizational Commitment : The Case Of Botswana. Journal of Pure \& Applied Sciences, Vol.2,No.3, October 2005 : 81-94.

[9] Kumar, Jalaja., Rao, B. D. (2007). Job Satisfaction of Teacher. New Delhi:Sachin Printers.

[10] Smartha (2009), Impact of job stress on job satisfaction. Indian journal of commerce and management studies, volume-II, (March 2011).

[11] Womble (2010), Impact Of Stress Factors On College Students Academic Performance. Journal, 35, 84-88.

[12] Liyana (2010), A Preliminary Study on Occupational Stress and Job Satisfaction among Male Navy Personnel at a Naval Base in Lumut, Malaysia. Uluslararası Sosyal Ara_tirmalar Dergisi The Journal of International Social Research Volume 2 / 9 Fall 2009

[13] Ahsan, N., Abdullah, Z., Gun Fie, D.Y., \& Shah Alam, S. (2009). A Study of Job Stress on Job Satisfaction among University Staff in Malaysia: Empirical Study. European Journal of Social Sciences, 8(1).

[14] RobbinP.S. (2002), Organizational Behavior Principles. Fifth edition, the publisher, Jakarta.

[15] Hofstede, G.H. (1983), "The cultural relativity of organizational practices and theories",Journal of International Business Studies,Fall, pp. 76-88.

[16] Kotter, J.P. and S.L. Hasket. 1997. Corporate Culture and Performance. PT Prenhallindo Simon \& Schuster (Asia) Pte Ltd, Jakarta. Lawler.

[17] Bunk, B.P., de Jonge, J., Ybema, J.F., and de Wollf, C.J. (1998): Psychological aspects of occupational stress. In P.J. D. Drenth, H. Thierry and C.J. de Wolff (Eds.): Work Psychology. Hove

[18] Ross, R., Altmaier, E., \& Russell, D. (1989). Job stress, social support, and burnout among counseling center staff. Journal of Counseling Psychology, 36,464-470

[19] Luthans, 2008 Luthans, F., Avey, J. B., Clapp-Smith, R., \& Li, W. 2008. More evidence on the value of Chinese workers' psychological capital: A potentially unlimited competitive resource? The International Journal of Human Resource Management, 19:818-827.

[20] Beehr, Terry A. dan John E. Newman, 1978, Job stress, employee health, and organizational effectiveness: a facet analysis, model, and literature review, Personnel Psychology

[21] Hasibuan. 2001. Human Resource Management. Revised Edition. Fourth edition

[22] Locke. Edwin.A, (1995), Interaction of Ability and Motivation in Performance, Perceptual and Motor Skills, Volume 21.

[23] Davis, K \& J. W. Newstrom, 1995, Organizational Behavior. Translation. Jakarta. Erlangga

[24] Robbins, S.P and Tomoty A. Judge, 1996. Organizational Behaviour, Seventh Edition, Prentice Hall Inc. New Jersey

[25] Bernardin, H. John \& Joice E, A. Russel, 1993. Human Resource Management, Mc. Graw-Hill, Inc.

[26] Marthis, R.I. and Jackson J.H. 2000. Human Resources management. New Jersey. Prentice Hall

[27] Singarimbun, Masri, (1989), Survey Research Methods, Prints Top-18, February 2006 (Revised Edition), Publisher Reader LP3ES, Jakarta

[28] Solimun (2011). Testing for Mediation Variable. What Necessary: International Conference of Basic Science. FMIPA of Brawijaya University. 